Article

\title{
Evaluation of La (III) and Ce(III) Adsorption from Aqueous Solution Using Carbon Nanotubes Adsorbent
}

\author{
Irene García-Díaz ", Francisco J. Alguacil, Esther Escudero, Félix A. López \\ 1 Centro Nacional de Investigaciones Metalurgicas (CENIM), Consejo Superior de Investigaciones Científicas \\ (CSIC), Madrid, Spain \\ * Correspondence: irenegd@cenim.csic.es; Tel.: +34-91-553-89-00 (I.G-D.)
}

\begin{abstract}
Since the 1960s Rare earths (REs) applications gradually have expanded to everyday life. REs have a great strategic importance in industrial and technological development, so it is expected an increase of their demand. Among the REs the European Commission considered Cerium and Lanthanum as critical raw materials. This research article studies the adsorption of Ce and La onto two carbon nanomaterials, multiwalled carbon nanotubes (MWCNT) and carboxylic functionalized multiwalled carbon nanotubes (MWCNT_ox). The latter has slightly more affinity for REs than MWCNT. The recovery percentage for Ce were 89 and $98 \%$ and in the case of for La were 99 and $92 \%$ using $0.8 \mathrm{~g}$ of MWCNT and $0.2 \mathrm{~g}$ of MWCNT_ox respectively. The adsorption process fits a pseudo second order kinetic model and the Langmuir isotherm best represented the metal uptake.
\end{abstract}

Keywords: adsorption; Lanthanum; Cerium; carbon nanotubes; rare earth

\section{Introduction}

Since 1960s, REs applications gradually have increases to everyday life until become to be elements which are critical in industrial development and modern technology, in this context these materials are designed also as technology-critical elements [1]. Although rare earths are more abundant than precious metals, the extraction of these are arduous, mainly due to two main reason, they are dispersed in ores deposit and they have similar chemical properties between them, making difficult their individual separation.

REs are widely used in different sectors such as clean energy, nuclear energy, chemical engineering, consumer electronics, advanced transportation, communication, metallurgy or medicine [2,3]. Their great applications are due to the configuration of their electrons in atomic structure and their extraordinary luminescent, catalytic, magnetic, optical, nuclear, electrical, metallurgical and chemical properties [4]. Moreover, the REs importance is also increasing due to their use in green carbon technologies, such as rechargeable car batteries, electronic devices, permanent magnets, wind turbines, and so on. [5]. 
The global demand of REs is increased and it is expected to experiment a notable growth over time [3]. The REs worldwide reserves are 120 million tons [6]. China is one of the highest supplier of these elements, with more than $70 \%$ of the global supply [7]. REs are considered by the European Commission as the most critical raw materials group with the highest supply risk [7]. However, in spite of their great applications and the larger amounts of REs-waste their recycling is still poorly development, in the EU only the $6 \%$ of the heavy REs and the $7 \%$ of the light REs are recovered [5][4][8][9].

Among REs, Nd (magnets include computer hard disk drive, mobile phones, electric hybrid vehicles, etc. [9][10][11]), Eu and $\mathrm{Y}$ (phosphors and luminescence in fluorescence lamps, LEDs, plasma screens, etc. [12][13]), and Ce and La (metal alloys, batteries, glass and catalysts, and rechargeable lithium-nickel batteries[14][15]) are considered the most critical one until 2025 [5].

Currently, the recycling of electric car batteries is a great social and technological challenge. Due to the environmental problem associate to their dangerous compounds, such among others, heavy metals. And the presence of valuable metals, particularly REs, cerium, lanthanum, neodymium and praseodymium which are forming part of the anode in the Ni-MH cell [6][16]. Nowadays, these kind of batteries are one of the most used [17].

Pyrometallurgical and hydrometallurgical process could be used in the battery recycling with the aim of REs recover. In the hydrometallurgical methods the batteries components are leaching in alkaline or acid medium, after machining [17], other stage included in hydrometallurgy methods is the selective separation and concentration from liquid effluent of the valuable metals, REs [6]. Some methods carried out to achieve it are among others, liquid-liquid extraction [18][19], adsorption[20], bioadsorption [21], ion exchange [14], precipitation [16][22][23].

Adsorption is an important methodology to recover these strategic elements from liquid effluents due to simplicity, flexibility, low cost and high efficiency [24][25][26][27]. Thus due to their high economic and technological value of REs joint to their supply risk it is essential the development or improvement technologies to recover them [28]. This article studies the viability to recover two strategic REs present in batteries, La and Ce.

In the last decades the study and the development of new adsorbent has been constant. Crane et al. studied the behavior of La adsorption onto nanoscale zero valent iron in an acid drainage medium [29], Iftekhar et al. [30] reviewed the factors that affect the La adsorption with different adsorbents, biosorbent, inorganic nano/composites, magnetic, silica, graphene oxides, activated carbon, etc.. Celso et al. [10] also presented a deep review about the adsorption capacity of different kind carbon nanomaterials.

In this sense this research article is focused on the adsorption of two of the most critical REs, Ce (III) and $\mathrm{La}(\mathrm{III})$ onto multiwalled carbon nanotubes (MWCNT) and carboxylic functionalized multiwalled carbon nanotubes (MWCNT-ox) in order to recover these valuable elements from liquid effluent.

\section{Materials and Methods}

\section{1.- Reagents:}

Commercial multiwalled carbon nanotubes (MWCNT) and multiwalled carbon nanotubes functionalized with carboxylic groups (MWCNT_ox) from Sigma-Aldrich were used as adsorbent without any further manipulation, Table 1 presents their main characteristic. All chemical, 
lanthanum nitrate hexahydrate $\left(\mathrm{La}\left(\mathrm{NO}_{3}\right)_{3} 6 \mathrm{H}_{2} \mathrm{O}\right)$ and cerium nitrate hexahydrate $\left(\mathrm{Ce}\left(\mathrm{NO}_{3}\right)_{3} 6 \mathrm{H}_{2} \mathrm{O}\right)$ from Sigma Aldrich, were used in AR grade.

Table 1.- MWCNT and MWCNT_ox characteristic

\begin{tabular}{llllllll}
\hline & $\begin{array}{l}\text { Purity } \\
\mathbf{( \% )}\end{array}$ & $\begin{array}{l}\text { Functionalization } \\
\text { grade(\%) }\end{array}$ & $\begin{array}{l}\text { BET } \\
\left(\mathbf{m}^{\mathbf{2}} \mathbf{g}^{-1}\right)\end{array}$ & $\begin{array}{l}\text { Average } \\
\text { diameter } \\
(\mathbf{n m})\end{array}$ & Density & $\begin{array}{l}\text { Length } \\
(\boldsymbol{\mu})\end{array}$ & $\begin{array}{l}\text { Method } \\
\text { of } \\
\text { process }\end{array}$ \\
\hline MWCNT & $>98 \%$ & ---- & 263 & $6-9$ & 2.1 & 5 & CVD \\
MWCNT_ox & $>80 \%$ & $>8$ & 307 & 9.5 & --- & 1.5 & CVD \\
\hline
\end{tabular}

CVD: Chemical vapour deposition

\section{2.- Z potential measurement and batch adsorption experiments:}

Z potential was measured using a Zetasizer Malvern Nano ZS at 25\%. Aqueous suspensions were prepared in $\mathrm{pH}$ solutions between 1 and 13 using solutions of $\mathrm{HCl}$ and $\mathrm{NaOH}$. The concentration of activated carbon was adjusted to a value of $0.1 \mathrm{~g} \mathrm{~L}^{-1}$.The suspensions were dispersed with a Bandelin Electconic Sonopuls HD 3100 sonicator, using an amplitude of $60 \%$ for $150 \mathrm{~s}$.

The adsorption of REs by nanomaterials were studied via batch adsorption experiment performed in a $0.5 \mathrm{~L}$ glass reactor provided of mechanical shaking. Standard aqueous solutions of 1 $\mathrm{g} \mathrm{L}^{-1}$ concentration of $\mathrm{La}$ and Ce respectively were prepared. The working REs solutions were prepared by diluting these. Different initial $\mathrm{pH}$ of the solutions was obtained with an acid solution of $0.1 \mathrm{M} \mathrm{HNO}$. The working REs solutions were put in to contact with the nanomaterials according to the different experimental conditions.

The residual concentration of Ce and La in aqueous solutions were determined by ICP (Agilent Technologies 5100 ICP-OES). The adsorption percentage was defined as:

$$
R_{C e / L a}=\left[\frac{C_{0}-C_{t}}{C_{t}}\right] \times 100
$$

Where $C_{0}$ and $C_{t}$ are the initial and time rare earth concentrations in the aqueous solution respectively (mg RE $\left.\mathrm{L}^{-1}\right)$.

REs load capacity onto the nanomaterials was calculated by mass balance, according to:

$$
q_{t}=\frac{\left(C_{0}-C_{t}\right) \cdot V}{m}
$$

Where $\mathrm{q}_{\mathrm{t}}$ is the amount La and Ce adsorbed (mg RE $\mathrm{g}^{-1}$ adsorbent), $\mathrm{V}$ is the volume of the solution $(0.2 \mathrm{~L})$ and $\mathrm{m}$ is the sorbent dosage $(\mathrm{g})$.

\section{Results}

It is assumed that the adsorption of both, La and Ce by the MWCNT responded to an adsorption process such as:

$$
\mathrm{MWCNT}_{\mathrm{s}}+\mathrm{Mn}^{+} \mathrm{a}_{4} \longrightarrow \mathrm{MWCNT}\left[\mathrm{Mn}^{+}\right]_{\mathrm{s}}
$$

Where MWCNT stands for the solid adsorbent an M for the meals.

Moreover, in the case of the functionalized carbon nanotubes the next reaction must be also considered.

$$
3(\mathrm{MWCNT}-\mathrm{COOH})_{\mathrm{s}}+\mathrm{M}^{3+}{ }_{\mathrm{aq}} \longleftrightarrow(\mathrm{MWCNT}-\mathrm{COOH})\left[\mathrm{M}^{3+}{ }_{\mathrm{aq}}\right]_{\mathrm{s}}
$$

Thus an ion exchange mechanism is also responsible for metal adsorption. 


\section{1.- Stirring speed}

Figure 1 shows $\mathrm{La}$ and Ce adsorption percentage against time at different stirring speed, the other experimental parameters were kept constant. REs adsorption onto MWCNT-Ox are not affected by the stirring speed, so the maximum REs percentages of removal become virtually independent of the stirring speed in the range between 500-1000 $\mathrm{min}^{-1}$, which indicates that the thickness of the aqueous diffusion layer and the aqueous resistance to mass transfer are minimum. Diffusion contribution of the aqueous species to the mass transfer process is assumed constant [31][32].

(a)
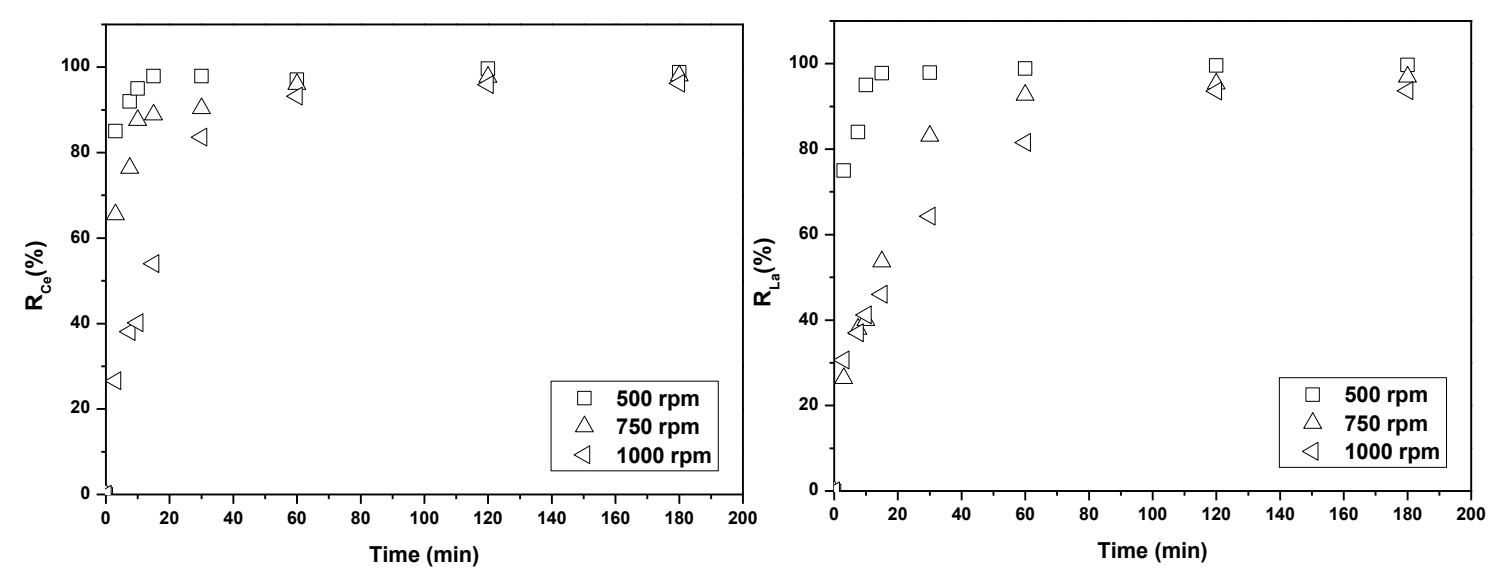

(b)
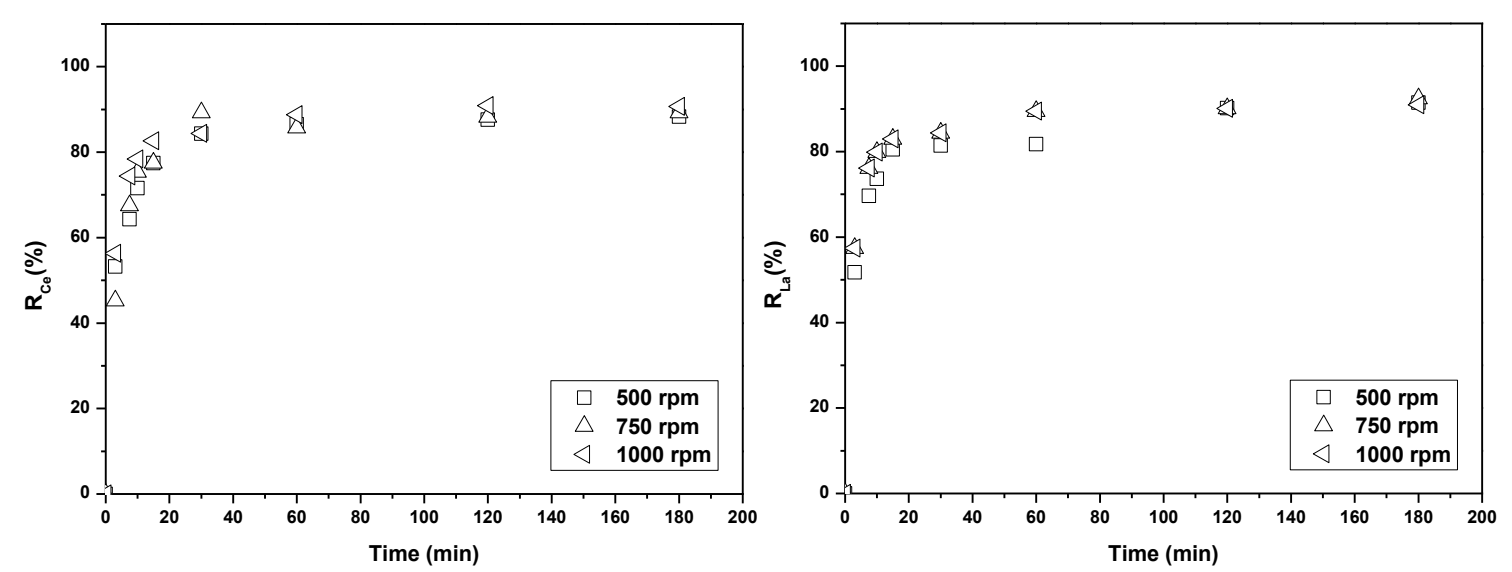

Figure 1.- Stirring speed effect on the adsorption of La and Ce onto the MWCNT and MWCNT-ox. (a) MWCNT: Experimental conditions: [Nanomaterials] $=0.8 \mathrm{~g}$, liquid $0.2 \mathrm{~L}$ of $[\mathrm{RE}]=0.01 \mathrm{~g} \mathrm{~L}^{-1} \mathrm{pH}=6$, $\mathrm{T}=298 \mathrm{~K}, \theta=$ variable rpm. (b) MWCNT_ox: Experimental conditions: [Nanomaterials] $=0.2 \mathrm{~g}$, liquid $0.2 \mathrm{~L}$ of $[\mathrm{RE}]=0.01 \mathrm{~g} \mathrm{~L}^{-1} \mathrm{pH}=6, \mathrm{~T}=298 \mathrm{~K}, \theta=$ variable rpm.

However, the behavior of MWCNT on REs adsorption was different, an increase in the stirring speed showed a decreases in the adsorption percentage at first elapsed time. This could be due to the 
agglomeration of carbon particles due to the Wan Der Waals Force and the consequent reduction in the active surface area of the adsorbent [33].

Figure 2 represents $\mathrm{Ct} / \mathrm{Cm}$ vs time. $\mathrm{Ct} / \mathrm{Cm}$ values are independent of the stirring speed when MWCNT_ox are used as adsorbent. However, in the case of the MWCNT, it is observed a slightly dependence at different stirring speed.

(a)
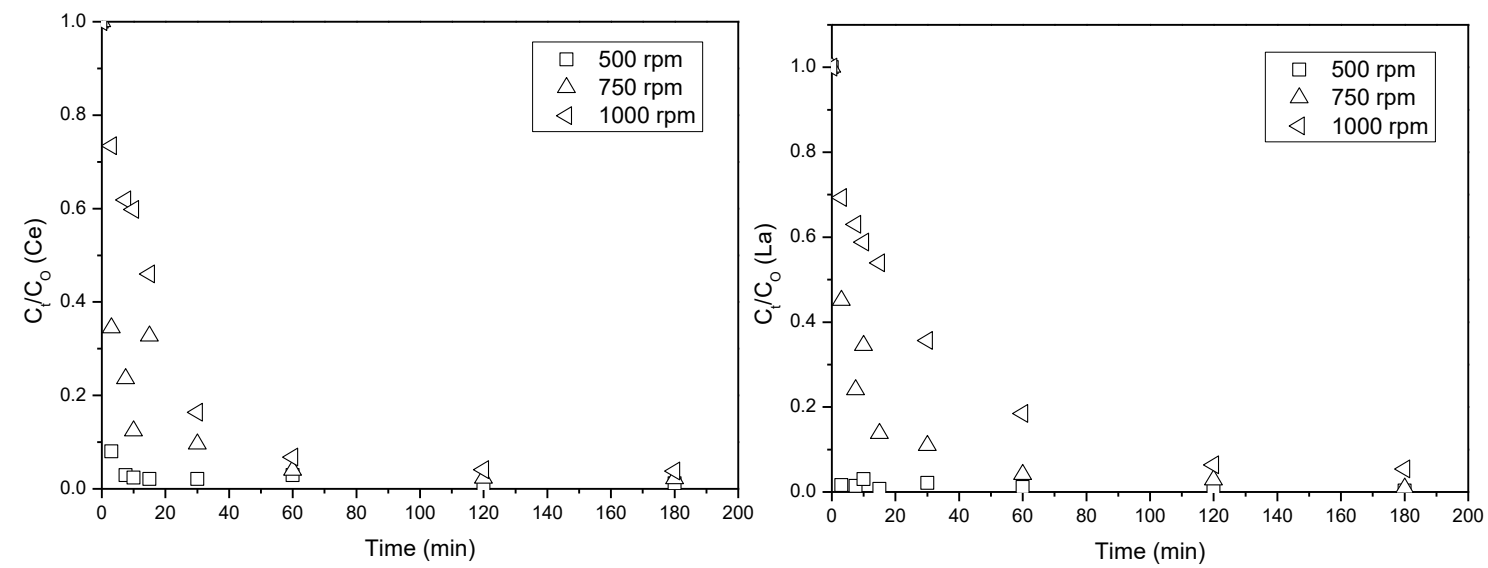

(b)
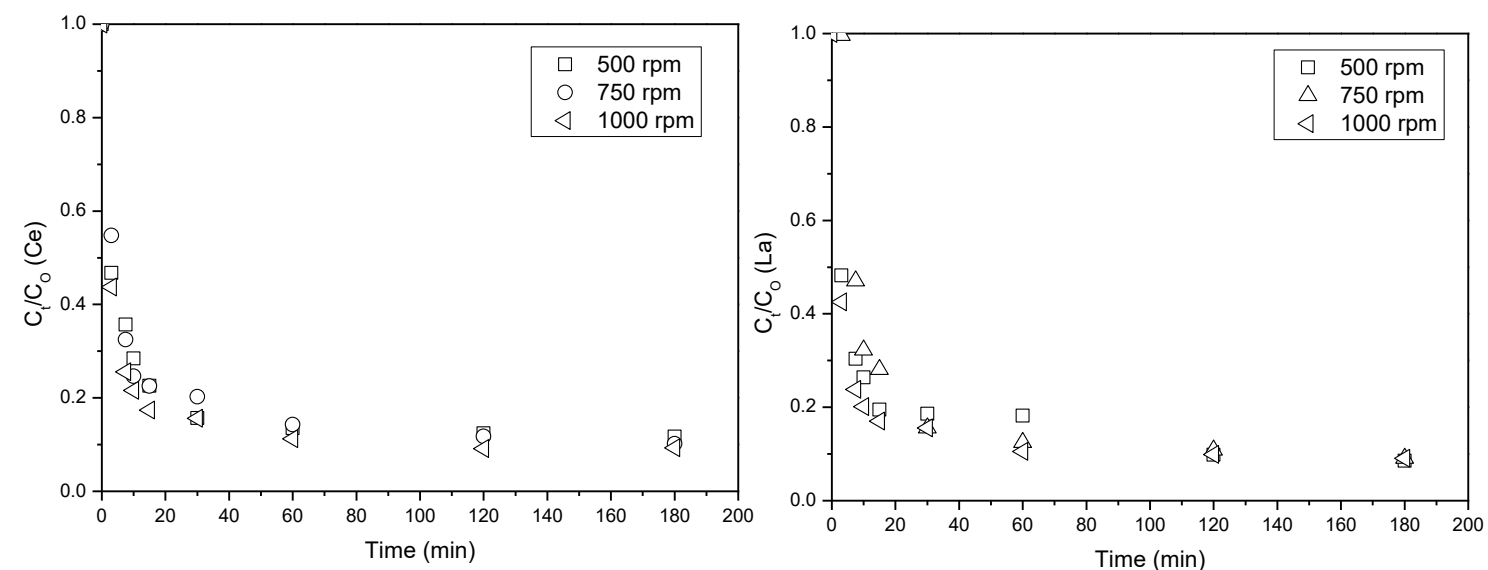

Figure 2.- $\mathrm{Ct} / \mathrm{Co}$ versus time to the adsorption of $\mathrm{La}$ and $\mathrm{Ce}$ onto the MWCNT and MWCNT-ox. (a) MWCNT: Experimental conditions: [Nanomaterials] $=0.8 \mathrm{~g}$, liquid $0.2 \mathrm{~L}$ of $[\mathrm{RE}]=0.01 \mathrm{~g} \mathrm{~L}^{-1} \mathrm{pH}=6, \mathrm{~T}=$ $298 \mathrm{~K}, \theta=$ variable rpm. (b) MWCNT_ox: Experimental conditions: [Nanomaterials] $=0.2 \mathrm{~g}$, liquid 0.2 $\mathrm{L}$ of $[\mathrm{RE}]=0.01 \mathrm{~g} \mathrm{~L}^{-1} \mathrm{pH}=6, \mathrm{~T}=298 \mathrm{~K}, \theta=$ variable rpm.

It should be noted here that the use of the functionalized carbon nanotubes greater improve the metal uptake, since these values are presented in Table 2 for the two adsorbents used in this investigation.

Table 2.- $\mathrm{qm}_{\mathrm{m}}\left(\mathrm{mg} \mathrm{g}^{-1}\right)$ values for REs adsorption at $500 \mathrm{rpm}$

\begin{tabular}{lll}
\hline & Ce & La \\
\hline MWCNT & 2.5 & 2.5 \\
\hline MWNT_ox & 8.8 & 9.1 \\
\hline
\end{tabular}

The equilibriums were reached for both carbon nanomaterials and both REs at $60 \mathrm{~min}$, all tests were carried out at $180 \mathrm{~min}$ ensuring to reach the equilibrium time. 


\section{2.-pH influence}

In adsorption, one of the most important parameter is the $\mathrm{pH}$ of the solution, it could affect the surface charge of the adsorbent and modify the adsorbate form. Therefore, it is essential its study [34].

Figure 3 shows $\mathrm{Z}$ potential of MWCNT and MWCNT_ox at different $\mathrm{pH}$ value. The isoelectronic points (IEP) are 1.22 and 0.26 for MWCNT and MWCNT_ox respectively. At pH values lower than the $\mathrm{pH}(\mathrm{IEP})$ the charge of the adsorbent surface is positive however, when the $\mathrm{pH}$ increases the surface has a negative charge. This change in the surface charge have a great influence in the adsorption properties of the adsorbent.

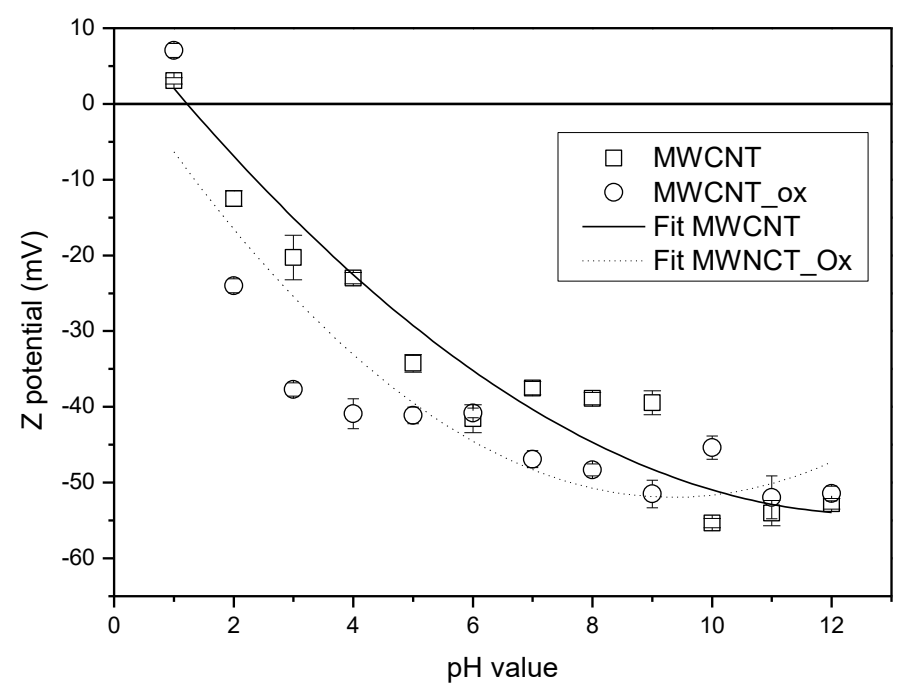

Figure 3.- Z potential Vs $\mathrm{pH}$

$\mathrm{pH}$ adsorption tests revealed that $\mathrm{La}$ and Ce uptake onto the nanomaterials are strongly pH-dependent, see Table 3.

Table 3.- La and Ce adsorption percentage at different $\mathrm{pH}$ values. Experimental conditions a) MWCNT: Experimental conditions: [Nanomaterials] $=0.6 \mathrm{~g}$, liquid $0.2 \mathrm{~L}$ of $[\mathrm{RE}]=0.01 \mathrm{~g} \mathrm{~L}^{-1} \mathrm{pH}=$ variable, $\mathrm{T}=298 \mathrm{~K}, \theta=500 \mathrm{rpm}$. b) MWCNT_ox: Experimental conditions: [Nanomaterials]= $0.2 \mathrm{~g}$, liquid $0.2 \mathrm{~L}$ of $[\mathrm{RE}]=0.01 \mathrm{~g} \mathrm{~L}^{-1} \mathrm{pH}=$ variable, $\mathrm{T}=298 \mathrm{~K}, \theta=1000 \mathrm{rpm}$.

\begin{tabular}{lcccc}
\hline \multicolumn{4}{l}{ Adsorption percentage } \\
\multirow{2}{*}{$\mathbf{p H}$} & MWCNT & \multicolumn{3}{l}{ MWNT_ox } \\
\cline { 2 - 5 } & Ce & La & Ce & La \\
\hline 4 & 0.4 & 12.8 & 0.0 & 39.7 \\
\hline 6 & 74.3 & 78.5 & 73.0 & 55.6 \\
\hline
\end{tabular}

In strong acidic conditions $(\mathrm{pH}=1)$ the adsorption percentage for La and Ce onto MWCNT and MWCNT-ox was negligible. This is due to the repulsive effect of the positive surface charge on the nanomaterials, see Figure 3.

However, an increase in the $\mathrm{pH}$, increases the adsorption percentage of $\mathrm{La}$ and $\mathrm{Ce}$ in both nanomaterials. This behavior could be due to that nanomaterials surface charge turns negative at $\mathrm{pH}$ value higher than the $\mathrm{pH}$ (IEP) 1.22 and 0.26 for MWCNT and MWCNT_ox, respectively, reaching a maximum adsorption percentage at $\mathrm{pH} 6, \mathrm{R}_{\mathrm{C}}=92.6 \%$ and $\mathrm{R}_{\mathrm{La}}=99.7 \%$ for MWCNT and $\mathrm{RCe}_{\mathrm{C}}=89.3 \%$ and $\mathrm{R}_{\mathrm{La}}=92.4 \%$ for MWCNT-Ox at $180 \mathrm{~min}$, see Table 2. At $\mathrm{pH}$ higher than 6, La and Ce precipitate such 
as the hydroxides, $\mathrm{La}(\mathrm{OH})_{3}$ and $\mathrm{Ce}(\mathrm{OH})_{3}$, see Figure 4. For further experiments, were performed at $\mathrm{pH} 6$.
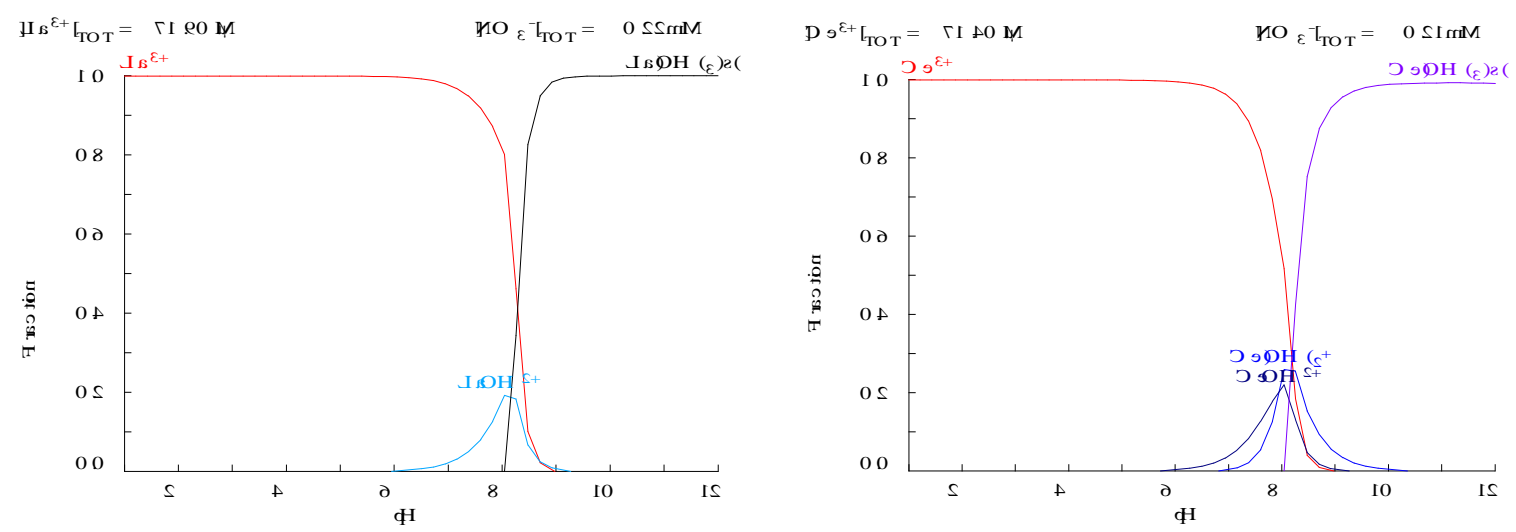

Figure 4.- Influence of the $\mathrm{pH}$ in chemical speciation

\section{3.- Effect of the REs concentration}

The adsorption behavior of solution with different concentrations of La and $\mathrm{Ce}$ at $\mathrm{pH}=6 \mathrm{using}$ MWCNT and MWCNT-Ox have been studied. Results shows in Figure 5.

The removal percentage depends on the initial metal concentration. An increase in the RE concentration decreases the adsorption percentage in both nanomaterials and both REs. This behavior is more noticeable when the concentration of the REs is high, around 0.04 and $0.08 \mathrm{~g} \mathrm{~L}^{-1}$. This decrease could be due to that both adsorbents have a fixed number of active sites, this higher metal concentrations could saturated these active sites [35]. The $\mathrm{q}_{\mathrm{m}}$ values are maximum to REs concentration of $0.04 \mathrm{~g} \mathrm{~L}^{-1}$ for both REs, being qece $=9.8 \mathrm{mg} \mathrm{g}^{-1}$, qeLa $=6.5 \mathrm{mg} \mathrm{g}^{-1}$ to MWCNT and qece $=49.3 \mathrm{mg} \mathrm{g}^{-1}$, qela $=54.2 \mathrm{mg} \mathrm{g}^{-1}$, to MWCNT_ox.

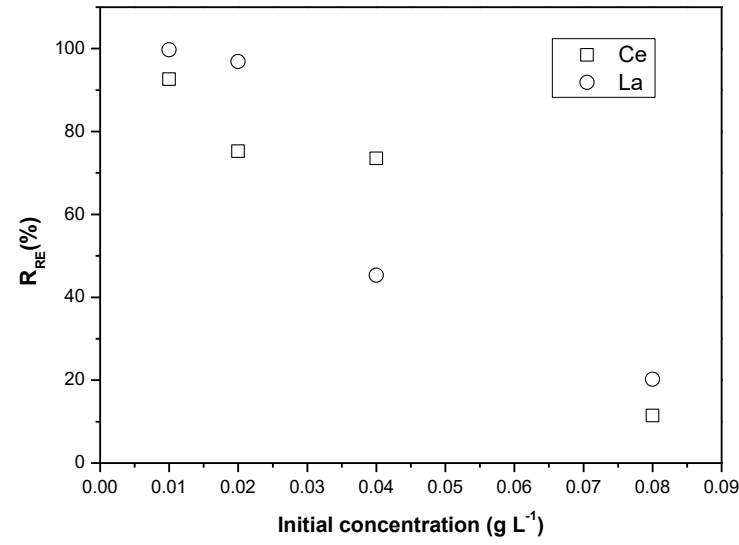

(a)

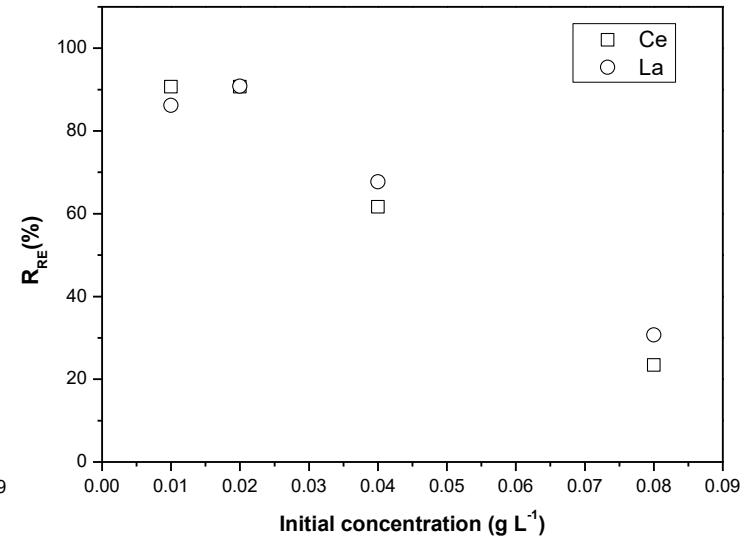

(b)

Figure 5.- Influence of the nanomaterial dosage. (a) MWCNT: Experimental conditions: [Nanomaterials] $=0.6 \mathrm{~g}$, liquid $0.2 \mathrm{~L}$ of $[\mathrm{RE}]=$ variable $\mathrm{g} \mathrm{L}^{-1} \mathrm{pH}=6, \mathrm{~T}=298 \mathrm{~K}, \theta=500 \mathrm{rpm}$, at equilibrium time. (b) MWCNT_ox: Experimental conditions: [Nanomaterials] $=0.1 \mathrm{~g}$, liquid $0.2 \mathrm{~L}$ of $[\mathrm{RE}]=$ variable $\mathrm{g} \mathrm{L}^{-1} \mathrm{pH}=6, \mathrm{~T}=298 \mathrm{~K}, \theta=1000 \mathrm{rpm}$, at equilibrium time. 


\section{4.- Dependence on nanomaterials dosage}

A series of experiments were done to investigate the influence of nanomaterials dosage in the adsorption of La and Ce. Figure 6 shows the REs adsorption percentage vs time. An increases in the MWCNT and MWCNT_ox dosages increased the RE adsorption. These results indicate that no agglomeration of carbon nanomaterials were observed, so these amounts are not enough to observe an adsorbent aggregation effect [35].

The adsorption percentage for both rare earths is higher than $95 \%$ using 3.0 or $4.0 \mathrm{~g} \mathrm{~L}^{-1}$ of MWCNT. However, it could be obtained similar values of adsorption percentage with a lower dosage of MWCNT-Ox nanomaterials, $1.0 \mathrm{~g} \mathrm{~L}^{-1}$. This behavior indicates that MWCNT_ox have more effective towards La and Ce adsorption to these experimental conditions, this could be due that the carboxylic group also contributes in rare earths adsorption.

(a)
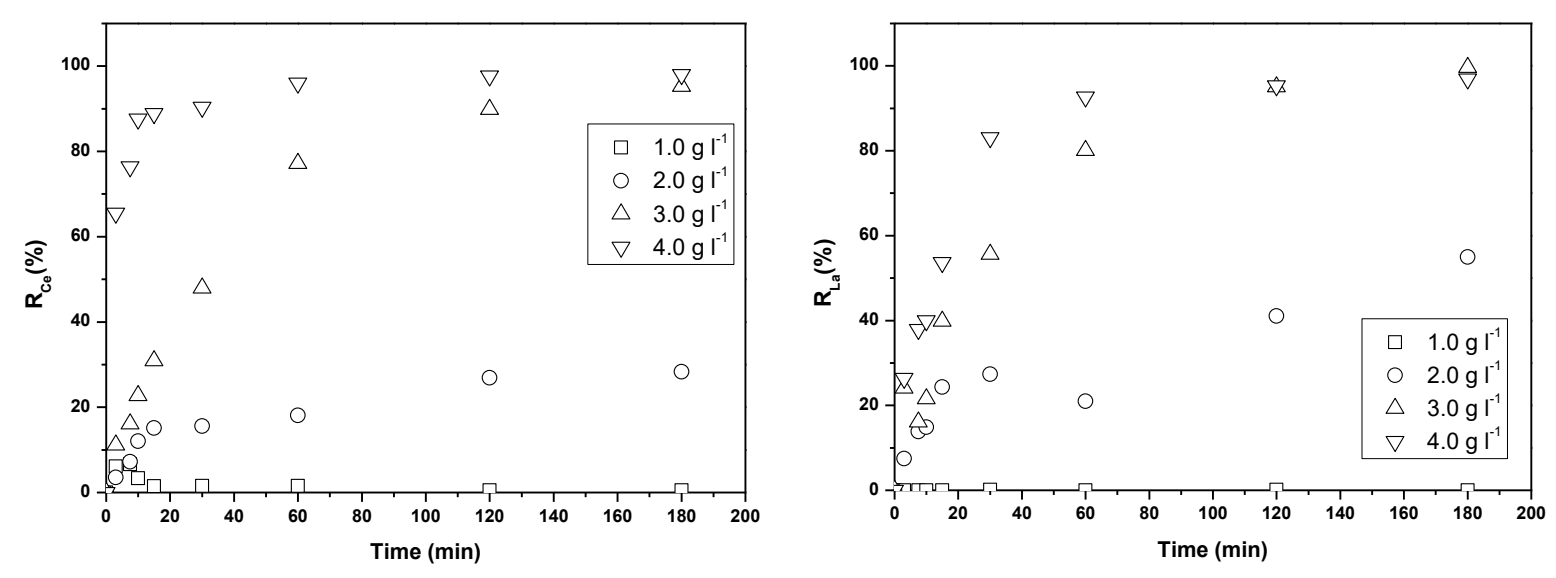

(b)
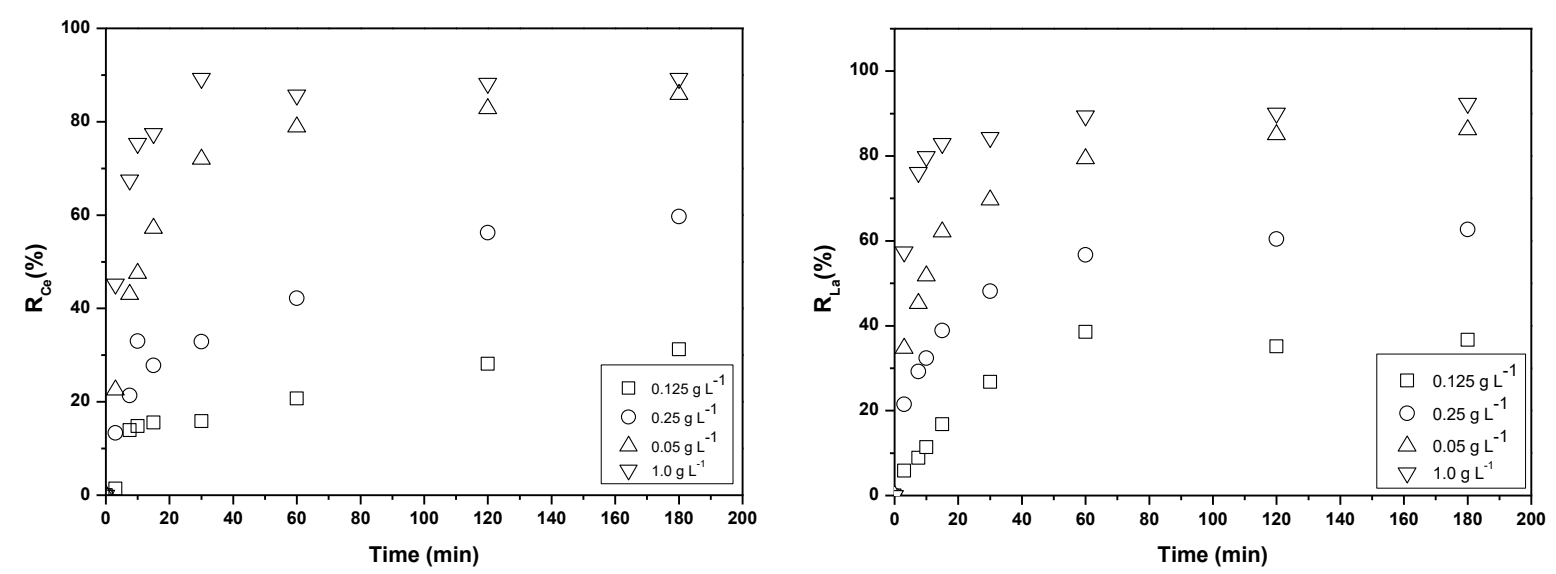

Figure 6.- Effect of nanomaterial dosage on the adsorption of La and Ce. (a) MWCNT: Experimental conditions: [Nanomaterials] = variable g, liquid $0.2 \mathrm{~L}$ of $[\mathrm{RE}]=0.01 \mathrm{~g} \mathrm{~L}^{-1} \mathrm{pH}=6, \mathrm{~T}=298 \mathrm{~K}, \theta=500 \mathrm{rpm}$. (b) MWCNT_ox: Experimental conditions: [Nanomaterials]= variable g, liquid $0.2 \mathrm{~L}$ of $[\mathrm{RE}]=0.01 \mathrm{~g}$ $\mathrm{L}^{-1} \mathrm{pH}=6, \mathrm{~T}=298 \mathrm{~K}, \theta=1000 \mathrm{rpm}$.

\section{5.- Kinetic study}


Experimental data were fit to various kinetic models to evaluate the adsorption rate.

- $\quad$ pseudo-first order [36]

$$
\ln \left(q_{e}-q_{t}\right)=\ln q_{e}-k_{1} t
$$

- $\quad$ pseudo-second order [37]

$$
\frac{t}{q_{t}}=\frac{1}{k_{2}\left(q_{e}\right)^{2}}+\left(\frac{1}{q_{e}}\right) t
$$

- $\quad$ Elovich model [38]

$$
q_{t=\frac{1}{\beta} \ln \alpha \cdot \beta+\frac{1}{\beta} \ln t}
$$

Where $\mathrm{q}_{\mathrm{e}}$ and $\mathrm{q}_{\mathrm{t}}\left(\mathrm{mg} \mathrm{g}^{-1}\right)$ are the sorption capacities at equilibrium and at time $\mathrm{t}(\mathrm{min})$ respectively, $\mathrm{k}_{1}$ is Lagergren first-order adsorption rate constant $\left(\mathrm{min}^{-1}\right), \mathrm{k}_{2}\left(\mathrm{~g} \mathrm{mg}^{-1} \mathrm{~min}^{-1}\right)$ is pseudo-second order constant. $\alpha$ is the initial adsorption rate $\left(\mathrm{mg} \mathrm{min}^{-1}\right)$ at contact time $\mathrm{t}=0 \mathrm{~min}$ and $\beta$ is the extent of surface coverage and activated energy $\left(\mathrm{g} \mathrm{mg}^{-1}\right)$. Table 4 and 5 summarized the calculated results.

Table 4.- Kinetic parameters for $\mathrm{La}(\mathrm{III})$ and $\mathrm{Ce}(\mathrm{III})$ adsorption onto MWCNT

\begin{tabular}{lllll}
\hline REs & Equation & Constant & & $\mathbf{R}^{2}$ \\
\hline \multirow{3}{*}{$\mathrm{Ce}$} & Pseudo-first & $0.0485 \mathrm{~min}^{-1}$ & $\mathrm{Qe}=0.894 \mathrm{mg} \mathrm{g}^{-1}$ & 0.9853 \\
\cline { 2 - 5 } & Pseudo-second & $0.0445 \mathrm{~g} \mathrm{mg}^{-1} \mathrm{~min}^{-1}$ & $\mathrm{Qe}=2.544 \mathrm{mg} \mathrm{g}^{-1}$ & 0.9945 \\
\cline { 2 - 5 } & Elovich & $\alpha=41.0593 \mathrm{mg} \mathrm{g}^{-1} \mathrm{~min}^{-1}$ & $\beta=2.185 \mathrm{~g} \mathrm{mg}^{-1}$ & 0.9532 \\
\hline \multirow{3}{*}{$\mathrm{La}$} & Pseudo-first & $0.0560 \mathrm{~min}^{-1}$ & $\mathrm{Qe}=0.879 \mathrm{mg} \mathrm{g}^{-1}$ & 0.9445 \\
\cline { 2 - 5 } & Pseudo-second & $0.0360 \mathrm{~g} \mathrm{mg}^{-1} \mathrm{~min}^{-1}$ & $\mathrm{Qe}=2.485 \mathrm{mg} \mathrm{g}^{-1}$ & 0.9925 \\
\cline { 2 - 5 } & Elovich & $\alpha=41.059 \mathrm{mg} \mathrm{g}^{-1} \mathrm{~min}^{-1}$ & $\beta=2.184 \mathrm{~g} \mathrm{mg}^{-1}$ & 0.9790 \\
\hline
\end{tabular}

Table 5.- Kinetic parameters for $\mathrm{La}(\mathrm{III})$ and $\mathrm{Ce}(\mathrm{III})$ adsorption onto MWCNT_ox

\begin{tabular}{ccccc}
\hline REs & Equation & Constant & & $\mathbf{R}^{2}$ \\
\hline \multirow{3}{*}{ Ce } & Pseudo-first & $0.1311 \mathrm{~min}^{-1}$ & $\mathrm{Qe}=0.739 \mathrm{mg} \mathrm{g}^{-1}$ & 0.9332 \\
\cline { 2 - 5 } & Pseudo-second & $0.0596 \mathrm{~g} \mathrm{mg}^{-1} \mathrm{~min}^{-1}$ & $\mathrm{Qe}=8.913 \mathrm{mg} \mathrm{g}^{-1}$ & 0.9998 \\
\cline { 2 - 5 } & Elovich & $\alpha=0.4237 \mathrm{mg} \mathrm{g}^{-1} \mathrm{~min}^{-1}$ & $\beta=0.363 \mathrm{~g} \mathrm{mg}^{-1}$ & 0.9190 \\
\hline \multirow{3}{*}{ La } & Pseudo-first & $0.1352 \mathrm{~min}^{-1}$ & $\mathrm{Qe}=0.730 \mathrm{mg} \mathrm{g}^{-1}$ & 0.9448 \\
\cline { 2 - 5 } & Pseudo-second & $0.0398 \mathrm{~g} \mathrm{mg}^{-1} \mathrm{~min}^{-1}$ & $\mathrm{Qe}=9.210 \mathrm{mg} \mathrm{g}^{-1}$ & 0.9989 \\
\cline { 2 - 5 } & Elovich & $\alpha=0.4425 \mathrm{mg} \mathrm{g}^{-1} \mathrm{~min}^{-1}$ & $\beta=0.343 \mathrm{~g} \mathrm{mg}^{-1}$ & 0.9403 \\
\hline
\end{tabular}

The data, in all the cases, fit better to the pseudo-second order kinetic model. The result obtained suggested that the adsorption could be also contributed with a pseudo-chemical adsorption process [39].

The rate law governing the adsorption of the rare earths onto the carbon nanomaterials was also evaluated. Three possible mechanism were studied [40].

- Film diffusion controlled process.

$$
\ln \left(1-\frac{q_{t}}{q_{e}}\right)=-K t
$$

- Particle diffusion controlled process.

$$
\ln \left(1-\left(\frac{q_{t}}{q_{e}}\right)^{2}\right)=-K t
$$

- Moving boundary process

$$
3-3\left(1-\frac{q_{t}}{q_{e}}\right)^{\frac{2}{3}}-2 \frac{q_{t}}{q_{e}}=K t
$$

Where $\mathrm{K}\left(\mathrm{min}^{-1}\right)$ is the rate constant model, qe and $\mathrm{qt}\left(\mathrm{mg} \mathrm{g}^{-1}\right)$ are the sorption capacities at equilibrium time respectively and $\mathrm{t}$ ( $\mathrm{min}$ ). 
Table 6.- Adsorption mechanisms kinetic parameter for La(III) and Ce(III) adsorption onto MWCNT

\begin{tabular}{cccc}
\hline REs & Equation & Constant & $\mathbf{R}^{\mathbf{2}}$ \\
\hline \multirow{3}{*}{$\mathrm{Ce}$} & Film diffusion & 0.0504 & 0.9788 \\
& Particle diffusion & 0.0429 & 0.9905 \\
& Moving boundary process & 0.0131 & 0.9667 \\
\hline \multirow{3}{*}{$\mathrm{La}$} & Film diffusion & 0.0375 & 0.9834 \\
& Particle diffusion & 0.0221 & 0.9934 \\
& Moving boundary process & 0.0079 & 0.9866 \\
\hline
\end{tabular}

Table 7.- Adsorption mechanisms kinetic parameter for $\mathrm{La}(\mathrm{III})$ and $\mathrm{Ce}(\mathrm{III})$ adsorption onto MWCNT_ox

\begin{tabular}{cccc}
\hline REs & Equation & Constant & $\mathbf{R}^{\mathbf{2}}$ \\
\hline \multirow{4}{*}{ Ce } & Film diffusion & 0.1191 & 0.8153 \\
& Particle diffusion & 0.0874 & 0.90601 \\
& Moving boundary process & 0.9601 & 0.8435 \\
\hline \multirow{3}{*}{ La } & Film diffusion & 0.1575 & 09047 \\
& Particle diffusion & 0.1038 & 0.9870 \\
& Moving boundary process & 0.0131 & 0.9667 \\
\hline
\end{tabular}

According to the value of $\mathrm{R}^{2}$, the model used to explain the REs adsorption onto these carbon nanomaterials is particle diffusion.

\section{6.- Adsorption isotherm models}

To obtain information about the adsorbent capacity and the amount of adsorbent required to effectively adsorption of the REs, it is necessary to obtain the corresponding adsorption isotherm [35]. The isotherm models used in this study were Freundlich and Lagmuir ones. The data were obtained varying the quantity of adsorbent. The linearized from of isotherm equations used [41][42] are shown in equations (11) and (12).

Langmuir model

Freundlich model

$$
\begin{gathered}
\frac{C_{e}}{q_{e}}=\frac{1}{q_{m} b}+\frac{1}{q_{m}} C_{e} \\
R_{L}=\frac{1}{1+b C_{o}}
\end{gathered}
$$

$$
\ln q_{e}=\ln K_{F}+\frac{1}{n} \ln C_{e}
$$

Where qe $\left(\mathrm{mg} \mathrm{g}^{-1}\right)$ is the sorption capacities at equilibrium time, $\mathrm{Ce}\left(\mathrm{mg} \mathrm{L}^{-1}\right)$ is RE concentration in the aqueous phase at equilibrium, $\mathrm{qm}\left(\mathrm{mg} \mathrm{g}^{-1}\right)$ is the maximum sorption capacity and b $\left(\mathrm{L} \mathrm{mg}^{-1}\right)$ is the Lagmuir sorption constant. RL is a dimensional constant separation [43], it provides an idea if the adsorption is considered favourable $(R L<1)$ and unfavourable $(R L>1), C 0\left(\mathrm{mg} \mathrm{L}^{-1}\right)$ is initial REs concentration. KF is the Freundlich constant $\left(\mathrm{L} \mathrm{g}^{-1}\right)$ and $1 / n$ is a heterogeneity factor constant, their value must be lesser than 1 for a favourable adsorption.

Table 8. Calculated isotherms parameters. MWCNT_ox Ce and La 


\begin{tabular}{cccccccc}
\hline & \multicolumn{3}{c}{ Lagmuir model } & \multicolumn{3}{c}{ Freundlich model } \\
& ${\mathrm{qm}\left(\mathrm{mg} \mathrm{g}^{-1}\right)}^{\mathrm{B}}\left(\mathrm{L} \mathrm{mg}^{-1}\right)$ & $\mathrm{RL}$ & $\mathrm{R}^{2}$ & $\mathrm{n}$ & $\mathrm{KF}\left(\mathrm{L} \mathrm{g}^{-1}\right)$ & $\mathrm{R}^{2}$ \\
$\mathrm{La}$ & 50.51 & 0.88 & 0.102 & 0.9968 & 4.359 & 23.038 & 0.6250 \\
$\mathrm{Ce}$ & 53.76 & 0.76 & 0.117 & 0.9970 & 4.871 & 43.053 & 0.8784 \\
\hline
\end{tabular}

Table 9. Calculated isotherms parameters. MWCNT Ce and La

\begin{tabular}{cccccccc}
\hline & \multicolumn{3}{c}{ Lagmuir model } & \multicolumn{4}{c}{ Freundlich model } \\
& $\mathrm{qm}\left(\mathrm{mg} \mathrm{g}^{-1}\right)$ & $\mathrm{B}\left(\mathrm{L} \mathrm{mg} \mathrm{m}^{-1}\right)$ & $\mathrm{R}$ & $\mathrm{R}^{2}$ & $\mathrm{n}$ & $\mathrm{KF}\left(\mathrm{L} \mathrm{g}^{-1}\right)$ & $\mathrm{R}^{2}$ \\
$\mathrm{La}$ & 9.13 & 6.44 & 0.015 & 0.9984 & 7.446 & 0.128 & 0.8448 \\
$\mathrm{Ce}$ & 16.26 & 0.56 & 0.152 & 0.9019 & 3.848 & 0.208 & 0.9058 \\
\hline
\end{tabular}

Table 8 and 9 show the isotherm parameters for both nanomaterials and both REs. The fit values, $\mathrm{R}^{2}$, show that the adsorptions were carried out by the Langmuir model, the isotherm assumed a monolayer sorption, where each adsorption position retains one atoms. The adsorption being energetically and sterically independent of the adsorbed quantity, these are sites identical. According to the value of the adimensional Langmuir constant $R L<1$, the adsorption process is considered favourable.

\section{7.- Desorption}

Desorption studied were also carried out. Based on the result of the $\mathrm{pH}$ influence, see Table 3, an increase in the $\mathrm{pH}$ promoted the adsorption percentage. Desorption studies were carried out in an acid medium. Accordingly, MWCNT and MWCNT_ox charged with La and Ce, were put in contact with $0.25 \mathrm{~L}$ of $0.1 \mathrm{M} \mathrm{HNO}_{3}, \mathrm{HCl}$ and $\mathrm{H}_{2} \mathrm{SO}_{4}$ solutions, during $30 \mathrm{~min}$, at ambient temperature. The solid/liquid relation was $0.4 \mathrm{~g} \mathrm{~L}^{-1}$, Table 10 shows the La and Ce concentration in nanomaterials.

Table 10.- La and Ce concentration in nanomaterials

\begin{tabular}{ccccc}
\hline & \multicolumn{2}{c}{ MWCNT } & \multicolumn{2}{c}{ MWNT_ox } \\
\hline qe $\left(\mathrm{mg} \mathrm{g}^{-1}\right)$ & Ce & La & Ce & La \\
\hline
\end{tabular}

Preliminary results show that the desorption percentage for MWCNT and MWXNT_ox using $\mathrm{HCl}$ and $\mathrm{HNO}_{3}$ are lower than $10 \%$ independently of the rare earth. An increase in the desorption percentage was observed with $\mathrm{H}_{2} \mathrm{SO}_{4}$ solution, the desorption percentage obtained for MWCNT and MWCNT_ox was 75 and 79\% for Ce and La and 84 and $87 \%$ for Ce and La respectively.

\section{Conclusions}

One of the main conclusion is the viability on the adsorption of La and Ce by multi-walled carbon nanotubes and carboxylic multiwalled functionalized.

The best conditions in the case of MWCNT are:

Cerium: Stirring speed $500 \mathrm{rpm}, \mathrm{pH}$ 6, Ce concentration $0.01 \mathrm{~g} \mathrm{~L}^{-1}$ and MWCNT dosage $0.8 \mathrm{~g}$ $\left(4.0 \mathrm{~g} \mathrm{~L}^{-1}\right)$, Ce adsorption percentage was $98 \%$.

Lanthanum: Stirring speed $500 \mathrm{rpm}, \mathrm{pH}$ 6, Ce concentration $0.01 \mathrm{~g} \mathrm{~L}^{-1}$ and MWCNT dosage 0.6 $\mathrm{g}\left(3.0 \mathrm{~g} \mathrm{~L}^{-1}\right)$, La adsorption percentage was $99 \%$.

The best conditions using MWCNT_ox are:

Cerium: adsorption percentage is independent of the stirring speed between 500 and $1000 \mathrm{rpm}$,

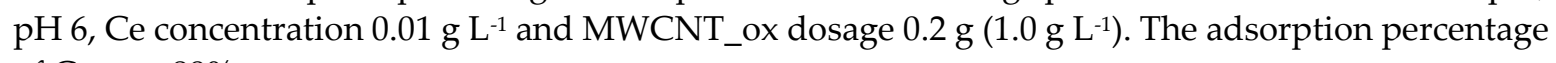
of Ce was $89 \%$.

Lanthanum: adsorption percentage are independent of the stirring speed between 500 and 1000 rpm, $\mathrm{pH}$ 6, Ce concentration $0.01 \mathrm{~g} \mathrm{~L}^{-1}$ and MWCNT_ox dosage $0.2 \mathrm{~g}\left(1.0 \mathrm{~g} \mathrm{~L}^{-1}\right)$, adsorption percentage of La was $92 \%$.

The result shows that MWNT_ox is more effective than MWCNT in the adsorption of La and Ce from aqueous solutions. In the systems studied the adsorption process fits to a pseudo-second order 
kinetic model, and Langmuir isotherm. The rate law which govern the adsorption is the particle diffusion model.

The higher desorption percentage of $\mathrm{La}$ and Ce for both nanomaterials were obtained using 0.1 $\mathrm{M} \mathrm{H}_{2} \mathrm{SO}_{4}$ solution rather than $\mathrm{HCl}$ and $\mathrm{HNO}_{3}$.

Author Contributions: Investigation, methodology, formal analysis, writing-original draft, writing-review \& editing: I.G.-D., investigation, supervision, writing-review \& editing, funding acquisition and project administration: F.A.L., investigation, supervision, writing-review \& editing: F.J.A., resources E.E. All authors have read and agreed to the published version of the manuscript.

Funding: This research was funded by EUROPEAN UNION'S HORIZON 2020, grant number No 776851 (carEService).

Acknowledgments: We acknowledge support of the publication fee by the CSIC Open Access Publication Support Initiative through its Unit of Information Resources for Research (URICI).

Conflicts of Interest: The authors declare no conflict of interest. The funders had no role in the design of the study; in the collection, analyses, or interpretation of data; in the writing of the manuscript, or in the decision to publish the results.

\section{References}

1. Klinger, J. M. A historical geography of rare earth elements: From discovery to the atomic age. Extr. Ind. Soc. 2015, 2, 572-580, doi:10.1016/j.exis.2015.05.006.

2. Zhou, B.; Li, Z.; Zhao, Y.; Zhang, C.; Wei, Y. Rare Earth Elements supply vs. clean energy technologies: new problems to be solve. Gospod. Surowcami Miner. 2016, 32, 29-44, doi:10.1515/gospo-2016-0039.

3. Goodenough, K. M.; Wall, F.; Merriman, D. The Rare Earth Elements: Demand, Global Resources, and Challenges for Resourcing Future Generations. Nat. Resour. Res. 2018, 27, 201-216, doi:10.1007/s11053-017-9336-5.

4. Binnemans, K.; Jones, P. T.; Blanpain, B.; Van Gerven, T.; Yang, Y.; Walton, A.; Buchert, M. Recycling of rare earths: A critical review. J. Clean. Prod. 2013, 51, 1-22, doi:10.1016/j.jclepro.2012.12.037.

5. Jacinto, J.; Henriques, B.; Duarte, A. C.; Vale, C.; Pereira, E. Removal and recovery of Critical Rare Elements from contaminated waters by living Gracilaria gracilis. J. Hazard. Mater. 2018, 344, 531-538, doi:10.1016/j.jhazmat.2017.10.054.

6. Omodara, L.; Pitkäaho, S.; Turpeinen, E.-M.; Saavalainen, P.; Oravisjärvi, K.; Keiski, R. L. Recycling and substitution of light rare earth elements, cerium, lanthanum, neodymium, and praseodymium from end-of-life applications - A review. J. Clean. Prod. 2019, 236, 117573, doi:10.1016/j.jclepro.2019.07.048.

7. EU, Report on critical raw materials and the circular economy - Publications Office of the EU,; 2017;

8. Jowitt, S. M.; Werner, T. T.; Weng, Z.; Mudd, G. M. Recycling of the rare earth elements. Curr. Opin. Green Sustain. Chem. 2018, 13, 1-7, doi:10.1016/j.cogsc.2018.02.008.

9. Gergoric, M.; Ravaux, C.; Steenari, B.-M.; Espegren, F.; Retegan, T. Leaching and Recovery of Rare-Earth Elements from Neodymium Magnet Waste Using Organic Acids. Metals (Basel). 2018, 8, 721, doi:10.3390/met8090721.

10. Cardoso, C. E. D.; Almeida, J. C.; Lopes, C. B.; Trindade, T.; Vale, C.; Pereira, E. Recovery of Rare Earth Elements by Carbon-Based Nanomaterials-A Review. Nanomaterials 2019, 9, 814, doi:10.3390/nano9060814.

11. Yoon, H.-S.; Kim, C.-J.; Chung, K.-W.; Kim, S.-D.; Lee, J.-Y.; Kumar, J. R. Solvent extraction, separation and recovery of dysprosium (Dy) and neodymium (Nd) from aqueous solutions: Waste recycling strategies for permanent magnet processing. Hydrometallurgy 2016, 165, 27-43, doi:10.1016/j.hydromet.2016.01.028.

12. Ogata, T.; Narita, H.; Tanaka, M. Adsorption mechanism of rare earth elements by adsorbents with diglycolamic acid ligands. Hydrometallurgy 2016, 163, 156-160, doi:10.1016/j.hydromet.2016.04.002. 
13. Tan, Q.; Li, J.; Zeng, X. Rare Earth Elements Recovery from Waste Fluorescent Lamps: A Review. Crit. Rev. Environ. Sci. Technol. 2015, 45, 749-776, doi:10.1080/10643389.2014.900240.

14. Kołodyńska, D.; Hubicki, Z.; Fila, D. Recovery of rare earth elements from acidic solutions using macroporous ion exchangers. Sep. Sci. Technol. 2019, 54, 2059-2076, doi:10.1080/01496395.2019.1604753.

15. Czerwinski, F. Cerium in aluminum alloys. J. Mater. Sci. 2020, 55, 24-72, doi:10.1007/s10853-019-03892-z.

16. Korkmaz, K.; Alemrajabi, M.; Rasmuson, Å. C.; Forsberg, K. M. Separation of valuable elements from NiMH battery leach liquor via antisolvent precipitation. Sep. Purif. Technol. 2020, 234, 115812, doi:10.1016/j.seppur.2019.115812.

17. Fila, D.; Hubicki, Z.; Kołodyńska, D. Recovery of metals from waste nickel-metal hydride batteries using multifunctional Diphonix resin. Adsorption 2019, 25, 367-382, doi:10.1007/s10450-019-00013-9.

18. Zhao, Z.; Qiu, Z.; Yang, J.; Ma, B.; Li, Z.; Lu, S.; Xu, Y.; Cao, L.; Zhang, W. Recovery of Rare Earth Element Cerium from Spent Automotive Exhaust Catalysts Using a Novel Method. Waste and Biomass Valorization 2019, doi:10.1007/s12649-019-00783-x.

19. Swain, N.; Mishra, S.; Acharya, M. R. Hydrometallurgical route for recovery and separation of samarium (III) and cobalt (II) from simulated waste solution using tri-n-octyl phosphine oxide - A novel pathway for synthesis of samarium and cobalt oxides nanoparticles. J. Alloys Compd. 2020, 815, 152423, doi:10.1016/j.jallcom.2019.152423.

20. Zheng, X.; Zhang, Y.; Bian, T.; Zhang, Y.; Li, Z.; Pan, J. Oxidized carbon materials cooperative construct ionic imprinted cellulose nanocrystals films for efficient adsorption of Dy(III). Chem. Eng. J. 2020, 381, 122669, doi:10.1016/j.cej.2019.122669.

21. Bai, R.; Yang, F.; Zhang, Y.; Zhao, Z.; Liao, Q.; Chen, P.; Zhao, P.; Guo, W.; Cai, C. Preparation of elastic diglycolamic-acid modified chitosan sponges and their application to recycling of rare-earth from waste phosphor powder. Carbohydr. Polym. 2018, 190, 255-261, doi:10.1016/j.carbpol.2018.02.059.

22. Yang, Y.; Lan, C.; Wang, Y.; Zhao, Z.; Li, B. Recycling of ultrafine NdFeB waste by the selective precipitation of rare earth and the electrodeposition of iron in hydrofluoric acid. Sep. Purif. Technol. 2020, 230, 115870, doi:10.1016/j.seppur.2019.115870.

23. Habashi, F. Extractive metallurgy of rare earths. Can. Metall. Q. 2013, 52, 224-233, doi:10.1179/1879139513Y.0000000081.

24. CHEN, Q. Study on the adsorption of lanthanum(III) from aqueous solution by bamboo charcoal. J. Rare Earths 2010, 28, 125-131, doi:10.1016/S1002-0721(10)60272-4.

25. Perez, J. P. H.; Folens, K.; Leus, K.; Vanhaecke, F.; Van Der Voort, P.; Du Laing, G. Progress in hydrometallurgical technologies to recover critical raw materials and precious metals from low-concentrated streams. Resour. Conserv. Recycl. 2019, 142, 177-188, doi:10.1016/j.resconrec.2018.11.029.

26. Ihsanullah; Abbas, A.; Al-Amer, A. M.; Laoui, T.; Al-Marri, M. J.; Nasser, M. S.; Khraisheh, M.; Atieh, M. A. Heavy metal removal from aqueous solution by advanced carbon nanotubes: Critical review of adsorption applications. Sep. Purif. Technol. 2016, 157, 141-161, doi:10.1016/j.seppur.2015.11.039.

27. Alguacil, F. J.; Lopez, F. A.; Rodriguez, O.; Martinez-Ramirez, S.; Garcia-Diaz, I. Sorption of indium (III) onto carbon nanotubes. Ecotoxicol. Environ. Saf. 2016, 130, 81-86, doi:10.1016/j.ecoenv.2016.04.008.

28. Wang, K.; Adidharma, H.; Radosz, M.; Wan, P.; Xu, X.; Russell, C. K.; Tian, H.; Fan, M.; Yu, J. Recovery of rare earth elements with ionic liquids. Green Chem. 2017, 19, 4469-4493, doi:10.1039/C7GC02141K.

29. Crane, R. A.; Sapsford, D. J. Sorption and fractionation of rare earth element ions onto nanoscale zerovalent iron particles. Chem. Eng. J. 2018, 345, 126-137, doi:10.1016/j.cej.2018.03.148.

30. Iftekhar, S.; Ramasamy, D. L.; Srivastava, V.; Asif, M. B.; Sillanpää, M. Understanding the factors affecting 
the adsorption of Lanthanum using different adsorbents: A critical review. Chemosphere 2018, 204, 413-430, doi:10.1016/J.CHEMOSPHERE.2018.04.053.

31. Ghodbane, I.; Hamdaoui, O. Removal of mercury(II) from aqueous media using eucalyptus bark: Kinetic and equilibrium studies. J. Hazard. Mater. 2008, 160, 301-309, doi:10.1016/j.jhazmat.2008.02.116.

32. Guechi, E.-K.; Hamdaoui, O. Evaluation of potato peel as a novel adsorbent for the removal of $\mathrm{Cu}$ (II) from aqueous solutions: equilibrium, kinetic, and thermodynamic studies. Desalin. Water Treat. 2016, 57, 1067710688, doi:10.1080/19443994.2015.1038739.

33. Alguacil, F.; Alcaraz, L.; García-Díaz, I.; López, F. Removal of Pb2+ in Wastewater via Adsorption onto an Activated Carbon Produced from Winemaking Waste. Metals (Basel). 2018, 8, 697, doi:10.3390/met8090697.

34. El-Naggar, M. E.; Radwan, E. K.; El-Wakeel, S. T.; Kafafy, H.; Gad-Allah, T. A.; El-Kalliny, A. S.; Shaheen, T. I. Synthesis, characterization and adsorption properties of microcrystalline cellulose based nanogel for dyes and heavy metals removal. Int. J. Biol. Macromol. 2018, 113, 248-258, doi:10.1016/j.ijbiomac.2018.02.126.

35. Akpomie, K. G.; Dawodu, F. A.; Adebowale, K. O. Mechanism on the sorption of heavy metals from binary-solution by a low cost montmorillonite and its desorption potential. Alexandria Eng. J. 2015, 54, 757767, doi:10.1016/j.aej.2015.03.025.

36. Galhoum, A. A.; Atia, A. A.; Mahfouz, M. G.; Abdel-Rehem, S. T.; Gomaa, N. A.; Vincent, T.; Guibal, E. Dy(III) recovery from dilute solutions using magnetic-chitosan nano-based particles grafted with amino acids. J. Mater. Sci. 2015, 50, 2832-2848, doi:10.1007/s10853-015-8845-z.

37. Ho, Y. S.; Mckay, G. The kinetics of sorption of basic dyes from aqueous solution by sphagnum moss peat. Can. J. Chem. Eng. 1998, 76, 822-827, doi:10.1002/cjce.5450760419.

38. Rudzinski, W.; Panczyk, T. Kinetics of Isothermal Adsorption on Energetically Heterogeneous Solid Surfaces: A New Theoretical Description Based on the Statistical Rate Theory of Interfacial Transport. J. Phys. Chem. B 2000, 104, 9149-9162, doi:10.1021/jp000045m.

39. Rahman, M. S.; Sathasivam, K. V. Heavy Metal Adsorption onto Kappaphycus sp. from Aqueous Solutions: The Use of Error Functions for Validation of Isotherm and Kinetics Models. Biomed Res. Int. 2015, 2015, 1-13, doi:10.1155/2015/126298.

40. Alguacil, F. J.; Lopez, F. A.; Rodriguez, O.; Martinez-Ramirez, S.; Garcia-Diaz, I. Sorption of indium (III) onto carbon nanotubes. Ecotoxicol. Environ. Saf. 2016, 130, doi:10.1016/j.ecoenv.2016.04.008.

41. Langmuir, I. THE ADSORPTION OF GASES ON PLANE SURFACES OF GLASS, MICA AND PLATINUM. J. Am. Chem. Soc. 1918, 40, 1361-1403, doi:10.1021/ja02242a004.

42. Freundlich, H. Über die Adsorption in Lösungen. Zeitschrift für Phys. Chemie 1907, 57U, doi:10.1515/zpch-1907-5723.

43. Foo, K. Y.; Hameed, B. H. Insights into the modeling of adsorption isotherm systems. Chem. Eng. J. 2010, 156, 2-10, doi:10.1016/j.cej.2009.09.013. 